\title{
Expression profiling of cancerous and normal breast tissues identifies microRNAs that are differentially expressed in serum from patients with (metastatic) breast cancer and healthy volunteers
}

Eleni van Schooneveld ${ }^{1,2^{*}+}$, Maartje CA Wouters ${ }^{3+}$, Ilse Van der Auwera ${ }^{2}$, Dieter J Peeters ${ }^{2,4}$, Hans Wildiers ${ }^{1,2}$, Peter A Van Dam², Ignace Vergote ${ }^{1,2}$, Peter B Vermeulen', Luc Y Dirix ${ }^{2}$ and Steven J Van Laere ${ }^{1,2}$

\begin{abstract}
Introduction: MicroRNAs (miRNAs) are a group of small noncoding RNAs involved in the regulation of gene expression. As such, they regulate a large number of cellular pathways, and deregulation or altered expression of miRNAs is associated with tumorigenesis. In the current study, we evaluated the feasibility and clinical utility of circulating miRNAs as biomarkers for the detection and staging of breast cancer.

Methods: miRNAs were extracted from a set of 84 tissue samples from patients with breast cancer and eight normal tissue samples obtained after breast-reductive surgery. After reverse transcription and preamplification, 768 miRNAs were profiled by using the TaqMan low-density arrays. After data normalization, unsupervised hierarchical cluster analysis (UHCA) was used to investigate global differences in miRNA expression between cancerous and normal samples. With fold-change analysis, the most discriminating miRNAs between both tissue types were selected, and their expression was analyzed on serum samples from 20 healthy volunteers and 75 patients with breast cancer, including 16 patients with untreated metastatic breast cancer. miRNAs were extracted from $200 \mu \mathrm{l}$ of serum, reverse transcribed, and analyzed in duplicate by using polymerase chain reaction (qRT-PCR).
\end{abstract}

Results: UHCA showed major differences in miRNA expression between tissue samples from patients with breast cancer and tissue samples from breast-reductive surgery $(P<0.0001)$. Generally, miRNA expression in cancerous samples tends to be repressed when compared with miRNA expression in healthy controls $(P=0.0685)$. The four most discriminating miRNAs by fold-change (miR-215, miR-299-5p, miR-411, and miR-452) were selected for further analysis on serum samples. All miRNAs at least tended to be differentially expressed between serum samples from patients with cancer and serum samples from healthy controls (miR-215, $P=0.094$; miR-299-5P, $P=0.019$; miR-411, $P=0.002$; and miR-452, $P=0.092$ ). For all these miRNAs, except for miR-452, the greatest difference in expression was observed between serum samples from healthy volunteers and serum samples from untreated patients with metastatic breast cancer.

Conclusions: Our study provides a basis for the establishment of miRNAs as biomarkers for the detection and eventually staging of breast cancer through blood-borne testing. We identified and tested a set of putative biomarkers of breast cancer and demonstrated that altered levels of these miRNAs in serum from patients with breast cancer are particularly associated with the presence of metastatic disease.

\footnotetext{
* Correspondence: eleni.vanschooneveld@gza.be

† Contributed equally

'Department of Oncology, University Hospitals Leuven and Catholic

University Leuven, Herestraat 49, Leuven, B3000 Belgium

Full list of author information is available at the end of the article
} 


\section{Introduction}

MicroRNAs (miRNAs) are a group of small (20 to 25 nt) noncoding RNAs able to regulate gene expression posttranscriptionally by binding to the 3'-untranslated region (UTR) of target mRNAs [1-3]. Since the initial discovery in Caenorhabditis elegans, more than 1,000 human miRNAs have been described, each of them targeting about 100 different mRNA molecules [4-6]. In this way, approximately $30 \%$ of all human genes are regulated by miRNAs $[7,8]$, thereby influencing several different pathways and processes in the cell, including development, differentiation, apoptosis, and cell proliferation [9-11].

As miRNAs are involved in fine-tuning gene expression in the cell $[1,2]$, deregulation of miRNA expression could lead to altered gene expression, which might contribute to the development of cancer [12]. Several studies have shown a differential miRNA-expression profile in cancer as compared with normal controls [13-15]. Although specific miRNAs can be upregulated in cancer [16], global miRNA downregulation is a common trait of human malignancies [13,17]. Furthermore, miRNAs are involved in the metastatic cascade, which is the most dismal feature of tumor biology with respect to patient prognosis.

MiRNA-expression profiling of primary tumor samples and their associated metastases identified both prometastatic and metastasis-suppressor miRNAs [15]. These miRNAs modulate the expression of metastasisassociated genes $[18,19]$, both directly and indirectly, by influencing the epigenetic machinery [20].

Breast cancer is the most frequent carcinoma and the second most common cause of cancer-related mortality in women [21]. In the past decade, it has been repeatedly shown that breast cancer is a heterogeneous condition consisting of at least five [22] but possibly more $[23,24]$ molecular subtypes. These molecular subtypes (Luminal A, Luminal B, Basal-like, ErbB2+, and Normallike) are characterized by specific mRNA-expression profiles. Blenkiron and colleagues [14] showed that these specific mRNA-expression profiles are at least partially attributable to differential miRNA expression. Also, Iorio and colleagues [25] identified a global pattern of miRNA deregulation in breast cancer tissue when compared with normal breast tissue, hinting at the importance of miRNA deregulation in the development of breast cancer in general.

As miRNAs appear to be critical regulators of tumor biology, their potential as prognostic and predictive biomarkers has recently been given attention. In addition, their great stability when compared with mRNA molecules, both in blood samples and in formalin-fixed, paraffin-embedded tissue samples, offers a great advantage
[26,27]. Levels of miRNAs do not substantially change when serum or plasma samples are subjected to freezethaw cycles, boiling, or maintenance at room temperature $[28,29]$. As the bloodstream is easily accessible, bloodborne miRNAs or circulating miRNAs hold the potential to serve as noninvasive biomarkers in oncology.

Recently, Heneghan and colleagues [30] showed that miRNA expression is detectable in whole blood, plasma, and the serum of cancer patients and healthy controls. In addition, miRNA-195 was identified as a potential biomarker for detecting noninvasive and early-stage breast disease [30].

The goal of this study was twofold. First, we aimed to identify patterns of miRNA deregulation in breast cancer. Therefore, we compare miRNA-expression patterns between breast tumor samples classified according to the molecular subtypes and between breast tumor samples and normal breast samples. We hypothesize that such profiles can be informative for breast cancer detection and prognosis and might assist in defining specific targets for future therapy.

Second, we investigated whether the expression levels of miRNAs are measurable in blood samples from patients with breast cancer and healthy volunteers and if such expression profiles are potentially useful for the detection and staging of breast cancer.

\section{Materials and methods}

\section{Patients and samples collection}

Tumor and blood samples were obtained from patients with breast adenocarcinoma treated in the Breast Clinic of the General Hospital Sint-Augustinus (Antwerp, Belgium). Tissue and serum samples were derived from two entirely independent populations. Each patient gave written informed consent. This study was approved by the Institutional Review Board. Clinicopathologic data are stored in a database in accordance with hospital privacy rules and are summarized in Table 1 . All tissue samples were stored in liquid nitrogen within 15 minutes after excision (median delay of 9 minutes). Healthy control tissue was obtained from breast-reductive surgery. None of the control samples showed pathologic changes. In total, 84 tumor samples and eight healthy control samples were included.

The collection of serum samples was described previously [31]. In brief, samples were prospectively obtained from 75 patients with breast cancer and 20 healthy volunteers. Patients were divided into three groups: four patients with localized breast cancer (group A), 55 patients with metastatic breast cancer receiving treatment (group B), and 16 patients with untreated metastatic breast cancer (group C). The blood samples of patients with metastatic disease were taken during the course of treatment. For all these 
Table 1 Clinicopathologic data

\begin{tabular}{|c|c|c|c|}
\hline Parameter & Group & Tissue $(n=84)$ & Serum $(n=75)$ \\
\hline \multirow[t]{4}{*}{ T status } & 1 & $27(32 \%)$ & $31(41 \%)$ \\
\hline & 2 & $27(32 \%)$ & $22(29 \%)$ \\
\hline & 3 & $6(7 \%)$ & $4(5 \%)$ \\
\hline & 4 & $24(29 \%)$ & $18(25 \%)$ \\
\hline \multirow[t]{5}{*}{$\mathrm{N}$ status } & 0 & $35(42 \%)$ & $28(37 \%)$ \\
\hline & 1 & $21(25 \%)$ & $15(20 \%)$ \\
\hline & 2 & $14(17 \%)$ & $10(13 \%)$ \\
\hline & 3 & $13(15 \%)$ & $9(12 \%)$ \\
\hline & 4 & $1(1 \%)$ & $13(18 \%)$ \\
\hline \multirow[t]{2}{*}{ M status } & 0 & $70(83 \%)$ & $4(5 \%)$ \\
\hline & 1 & $14(17 \%)$ & $71(95 \%)$ \\
\hline \multirow[t]{2}{*}{ ER status } & Negative & $25(30 \%)$ & $23(31 \%)$ \\
\hline & Positive & $59(70 \%)$ & $52(69 \%)$ \\
\hline \multirow[t]{2}{*}{ PR status } & Negative & $45(54 \%)$ & $36(48 \%)$ \\
\hline & Positive & $39(46 \%)$ & $39(52 \%)$ \\
\hline \multirow[t]{2}{*}{ ErbB2 status } & Negative & $62(74 \%)$ & $49(65 \%)$ \\
\hline & Positive & $22(26 \%)$ & $26(35 \%)$ \\
\hline \multirow[t]{3}{*}{ Grade } & 1 & $9(11 \%)$ & 14 (19\%) \\
\hline & 2 & $32(38 \%)$ & 29 (39\%) \\
\hline & 3 & $43(51 \%)$ & $32(42 \%)$ \\
\hline \multirow[t]{4}{*}{ Stage } & 1 & $24(29 \%)$ & $19(25 \%)$ \\
\hline & $\|$ & $20(24 \%)$ & 14 (19\%) \\
\hline & III & $27(32 \%)$ & $22(29 \%)$ \\
\hline & IV & $13(15 \%)$ & $20(27 \%)$ \\
\hline \multirow[t]{2}{*}{ Disease status } & Progressive & $29(35 \%)$ & 47 (63\%) \\
\hline & Nonprogressive & $55(65 \%)$ & $28(37 \%)$ \\
\hline
\end{tabular}

ErbB2 status is determined by using the Hercep test with confirmation by $\mathrm{FISH}$. Disease status is determined by using the RECIST criteria.

samples, circulating tumor cells (CTCs) were enumerated by using the CellSearch system (Veridex, Warren, NJ, USA), CK19, and mammaglobin mRNA expression was recorded, the ADNAgen test for detection of CTCs was performed, and levels of total plasma DNA and serum methylated DNA for ESR1, RASSF1A, or APC1 were measured in earlier studies $[31,32]$. Disease status was assessed by using the RECIST (Response Evaluation Criteria in Solid Tumors) criteria without knowledge of the patient's CTC or circulating DNA results [33]. Stable disease was measured up to 8 weeks after the initiation of therapy. In addition, we collected blood samples from an additional series of 18 unselected patients to evaluate which blood medium (that is, serum, plasma, platelet-rich plasma, whole blood, or peripheral blood mononuclear cells (PBMCs)) was best suited for extraction of small RNAs (sRNAs).

RNA extraction, cDNA synthesis, and miRNA quantification for tissue samples

After tissue disruption, total RNA was extracted by using the mirVana miRNA Isolation Kit (Ambion, Austin, TX, USA) according to the manufacturer's instructions for total RNA isolation. In brief, the sample was homogenized in a denaturing lysis solution, followed by an acid-phenol:chloroform extraction. Thereafter, the sample was purified on a glass-fiber filter and quantified by using the Nanodrop ND1000 (NanoDrop Technologies, Waltham, MA, USA). Total RNA (100 ng) was converted to cDNA by priming with two pools of stem-looped RT primers (Megaplex RT Primers, Human Pool A \& B; Applied Biosystems, Foster City, CA, USA) in combination with the TaqMan MicroRNA Reverse Transcription Kit (Applied Biosystems), allowing the simultaneous transcription of 377 unique miRNAs and six endogenous controls per primer pool. In brief, 3 $\mu \mathrm{l}$ of total RNA was supplemented with RT primer mix (×10), dNTPs with dTTP $(100 \mathrm{mM})$, Multiscribe Reverse Transcriptase $(50 \mathrm{U} / \mu \mathrm{l}), \mathrm{RT}$ buffer $(\times 10), \mathrm{MgCl}_{2}(25$ $\mathrm{m} M)$, and RNase inhibitor $(20 \mathrm{U} / \mu \mathrm{l})$ in a total reaction volume of $7.5 \mu \mathrm{l}$.

Thermal-cycling conditions were as follows: 40 cycles at $16^{\circ} \mathrm{C}$ for 2 minutes, $42^{\circ} \mathrm{C}$ for 1 minute, and $50^{\circ} \mathrm{C}$ for 1 second, followed by reverse transcriptase inactivation at $85^{\circ} \mathrm{C}$ for 5 minutes. The Megaplex RT product $(2.5$ $\mu \mathrm{l})$ was preamplified by using the TaqMan PreAmp Master Mix (Applied Biosystems) and preamplification primers in a $25-\mu \mathrm{l}$ PCR reaction. For each pool of stemlooped $\mathrm{RT}$ primers in the cDNA reaction, a different pool of PreAmp Primers (Human Pool A \& B; Applied Biosystems) was used. Thermal-cycling conditions were as follows: $95^{\circ} \mathrm{C}$ for 10 minutes, $55^{\circ} \mathrm{C}$ for 2 minutes, and $75^{\circ} \mathrm{C}$ for 2 minutes, followed by 12 cycles of $95^{\circ} \mathrm{C}$ for 15 seconds and $60^{\circ} \mathrm{C}$ for 4 minutes. MiRNA quantification was performed with the TaqMan Human MicroRNA Array sets A \& B (Applied Biosystems), each containing 384 TaqMan miRNA assays. The PreAmp product was diluted fourfold. Each of the eight wells was loaded with $100 \mu \mathrm{l}$ of PCR reaction mix, containing $50 \mu \mathrm{l}$ of TaqMan Universal PCR Master Mix, no AmpErase uracil $N$-glycosylase (UNG) (Applied Biosystems), $1 \mu \mathrm{l}$ of diluted PreAmp product, and $49 \mu \mathrm{l}$ of nuclease-free water. Thermal-cycling conditions were as follows: $94.5^{\circ}$ $\mathrm{C}$ for 10 minutes, followed by 40 cycles at $97^{\circ} \mathrm{C}$ for 30 seconds and $59.7^{\circ} \mathrm{C}$ for 1 minute. All PCR reactions were performed on a 7900HT Fast Real-Time PCR System (Applied Biosystems).

To test the efficiency of the miRNA assays, we compared the Ct-values of an undiluted sample with those of a 10-fold diluted sample. To evaluate the linearity of the preamplification, we compared the Ct-values of all miRNAs on both array cards for one sample before and after preamplification. The reproducibility of the arrays was tested by analyzing four samples in duplicate. The robustness of the TaqMan RT-PCR method was investigated by comparing the qRT-PCR miRNA expression profile of 12 samples with their miRNA expression 
profile obtained by using the nCounter Analysis System (Nanostring Technologies, Seattle, WA, USA). This system is a medium-high throughput gene-expression quantification system with PCR sensitivity that uses a novel digital technology based on direct multiplexed measurement of miRNA expression. Besides a direct quantification, the workflow incorporates only one enzymatic step (ligase step to enable tagging of the miRNAs) instead of three enzymatic steps in the qRT-PCR workflow, thereby substantially reducing the possibility for technical bias. The nCounter experiment was performed in collaboration with the VIB MicroArray Facility (O\&N, UZ Gasthuisberg, Leuven, Belgium).

\section{RNA extraction, cDNA synthesis, and miRNA quantification for blood samples}

First, we evaluated which blood medium was best suited for the extraction of sRNA molecules. Therefore, plasma, platelet-rich plasma, serum, whole blood, and PBMCs were obtained from 18 patients with breast cancer. Peripheral blood was collected in a 9-ml EDTA tube, from which $3 \mathrm{ml}$ of whole blood was transferred into a cryovial while the remaining blood was centrifuged slowly ( $150 \mathrm{~g}, 20$ minutes $)$ at $4^{\circ} \mathrm{C}$ to generate platelet-rich plasma. Plasma and PBMCs were obtained in an 8-ml CPT tube, which was centrifuged (1,650 g, 20 minutes) at room temperature. Plasma and PBMC aliquots were transferred into separate cryovials. Finally, 8 $\mathrm{ml}$ blood was collected in serum separator tubes (Becton Dickinson, Franklin Lakes, NJ, USA) and centrifuged $(2,000 g, 10$ minutes $)$ at room temperature. All samples were stored at $-80^{\circ} \mathrm{C}$ until use.

sRNA was isolated from $200 \mu \mathrm{l}$ of each medium by using the microRNA Isolation Kit (BioChain Institute Inc, Hayward, CA, USA) according to the manufacturer's instruction for sRNA purification. In brief, after adding lysis buffer to the sample for homogenization, 20 $\mu \mathrm{l}$ of Proteinase K solution (Qiagen, Valencia, CA, USA) was added and incubated for 10 minutes at $75^{\circ} \mathrm{C}$ to digest the excess of proteins released after addition of the lysis buffer. This was followed by an acid-phenol: chloroform extraction. Small and large RNAs were separated by using a centrifugation step, after which the large RNAs were retained on a glass-fiber filter. The sRNA molecules were recovered from the flow-through by purifying them on a second glass-fiber filter, and their concentration and purity (A260/A280 and A260/ A230) was recorded by using the NanoDrop ND1000 (NanoDrop Technologies, Waltham, MA, USA). The concentrations were compared by using a KruskalWallis test with Tukey HSD post hoc testing.

To evaluate circulating miRNA expression in blood samples from 20 healthy volunteers and 75 patients with breast cancer, we isolated total RNA, as described before. Isolated total RNA was reverse transcribed to produce cDNA by using the TaqMan MicroRNA Reverse Transcription Kit (Applied Biosystems) by priming with TaqMan MicroRNA Assays (Applied Biosystems) directed at 4 miRNAs identified by comparing tumor tissue with normal breast tissue (vide supra). In addition, miR-16 expression was determined as a normalization factor. In brief, each $15-\mu \mathrm{l}$ reaction contained $0.15 \mu \mathrm{l} 100 \mathrm{mM}$ dNTPs with dTTP, $1.0 \mu \mathrm{l}$ Multiscribe Reverse Transcriptase $(50 \mathrm{U} / \mu \mathrm{l}), 1.50 \mu \mathrm{l} \mathrm{RT}$ Buffer $(\times 10), 0.19 \mu \mathrm{l}$ RNase Inhibitor $(20 \mathrm{U} / \mu \mathrm{l}), 4.16 \mu \mathrm{l}$ nuclease-free water, $5.0 \mu \mathrm{l}$ total RNA, and $3.0 \mu \mathrm{l}$ RT primer. Thermal-cycling conditions were 30 minutes at $16^{\circ} \mathrm{C}, 30$ minutes at $42^{\circ} \mathrm{C}$, and 5 minutes at $85^{\circ} \mathrm{C}$. Each $20-\mu \mathrm{l}$ reaction for the real-time quantitative PCR contained $1.0 \mu \mathrm{l}$ real-time primer, $1.33 \mu \mathrm{l}$ product from RT reaction, $10.0 \mu \mathrm{l}$ TaqMan Universal PCR Master Mix, no AmpErase UNG (Applied Biosystems), and $7.67 \mu \mathrm{l}$ nuclease-free water. The reactions were performed in duplicate on a 7900HT Fast Real-Time PCR System in the 9600 emulation mode, with conditions of $10 \mathrm{~min}$ utes at $95^{\circ} \mathrm{C}$, followed by 40 cycles of 15 seconds at $95^{\circ}$ $\mathrm{C}$ and 1 minute at $60^{\circ} \mathrm{C}$. The mirVana miRNA Reference Panel (Ambion, Austin, TX, USA) was included in each PCR plate in a 2,000-fold dilution to correct for between-plate differences.

\section{Statistics and bioinformatics}

All subsequent analyses were performed by using BioConductor in $\mathrm{R}$. To reduce technical variation, the miRNA assays with a PCR efficiency outside the range of $2 \log (10)$ or $3.32 \pm 25 \%$ [34] and those with Ct values above 35 in at least $25 \%$ of the cases were filtered out. By using efficient and informative miRNA assays only, we calculated the mean difference between the $\mathrm{Ct}$ values of one sample before and after preamplification. To avoid technical bias, we excluded miRNA assays with a difference in $\mathrm{Ct}$ values before and after preamplification outside the range of the mean value $\pm 25 \%$. For the final set of miRNAs, we calculated the mean expression level per sample and used this value as a normalization factor to account for differences in input material [35]. Relative miRNA expression levels were calculated by using the $\Delta$ Ct-method [36] and log2-transformed to obtain a normal distribution. To investigate assay reproducibility, we correlated the expression profiles of the duplicate samples by using the Spearman correlation coefficient.

An additional technical validation was done by performing a pairwise correlation analysis between the miRNA profiles obtained by qRT-PCR and the nCounter Analysis System for the 12 samples analyzed on both platforms. Both correlation analyses were done by using the normalized expression profiles of the 327 common miRNAs only. 
Unsupervised hierarchical cluster analysis (UHCA), with the Manhattan distance as similarity metric and Ward clustering as the dendrogram drawing method, was performed to visualize global themes in the expression data. We classified samples according to the miRNA-centroids for molecular subtypes published by Blenkiron et al. [14]. Therefore, we correlated the molecular subtype-specific miRNA-expression profiles of each sample with each of the five miRNA-based expression centroids by using the Spearman correlation coefficient.

The resulting classification was compared with the UHCA result. For 66 samples with available Affymetrixprofiles, we compared the correlation coefficients between the samples grouped according to the SSP (single-sample predictor)-defined molecular subtype classification [37] obtained through mRNA-expression profiling reported in earlier studies [38,39]. Significance was assessed by using the Mann-Whitney $U$ tests.

Next, we aimed to identify molecular subtype-specific miRNAs. Therefore, we performed a pairwise comparison of the different molecular subtypes, defined through mRNA-expression profiling, by using regression analysis with the limma-package. False Discovery Rate (FDR) correction was performed by using the Benjamini and Hochberg step-up procedure. For each subtype, we crossed the lists of differentially expressed miRNAs resulting from the pairwise comparisons involving the desired subtype in search for common miRNAs.

By using regression analysis, we identified differentially expressed miRNAs between normal and tumor samples. Resulting $P$ values were corrected for false discovery, as described earlier. To investigate global over- or underexpression in normal samples, we calculated the median expression level of the differentially expressed miRNAs per sample. These median expression values were compared by using Mann-Whitney $U$ testing. The top four differentially expressed miRNAs by fold-change were selected for further analysis. For these miRNAs, we identified target mRNAs in at least two of three public databases (PicTar, TargetScan, and Miranda) by using the RmiR-package. These target-gene lists were subjected to Ingenuity Pathway Analysis (IPA) to study the implications of the identified miRNAs in cancer biology.

Expression levels of circulating miRNAs were calculated with miR-16 as normalization factor. Raw Ct values measured in the miRNA Reference Panel were subtracted from the $\mathrm{Ct}$ values measured in the samples, yielding a between-plate corrected expression value for each miRNA per $200 \mu \mathrm{l}$ of serum. The miR-16 normalized expression value was calculated by subtracting the between-plate corrected expression value for miR-16 from the between-plate corrected expression values for the remaining miRNAs ( $\Delta \Delta \mathrm{Ct}$-method). Relative expression values were calculated by using the $2^{-\Delta \Delta C t}$ method [36]. To compare the expression data with categoric variables, the Mann-Whitney $U$ test was performed. To compare expression data with continuous variables, Spearman correlation coefficients were calculated.

\section{Results}

Technical validation of miRNA profiling in tissue samples First, we excluded 292 miRNA assays (A panel, 83; B panel, 209) with a Ct value above 35 in at least $25 \%$ of the samples, leading to 462 informative miRNAs (A panel, 294; B panel, 168). Before performing the data normalization, we checked the PCR efficiencies of all miRNA assays on the array cards by performing a 10fold dilution series and subtracting the $\mathrm{Ct}$ values of the undiluted sample from the $\mathrm{Ct}$ values of the diluted sample. Theoretically, for an efficient PCR reaction, this difference should equal $2 \log (10)$ or 3.32 . We excluded 23 (A panel, 14; B panel, 9) miRNA assays with PCR-efficiencies outside the range of $3.32 \pm 25 \%$. The distribution of the PCR efficiencies and the cut-off values for exclusion are shown in Figure 1A.

Next we evaluated the linearity of the preamplification by comparing the miRNA-expression profiles of a sample before and after preamplification. This analysis was done for 439 miRNAs that remained after exclusion of noninformative and inefficient miRNA assays. The mean difference between the $\mathrm{Ct}$ values before and after preamplification was 8 , and miRNA assays with a difference in $\mathrm{Ct}$ value outside the range of $8 \pm 25 \%$ were excluded from further analysis (A panel, 30; B panel, 36). As such, the final data set consisted of 373 miRNAs that were normalized by using the $\Delta \mathrm{Ct}$ method with the median Ct value per sample as normalization factor. The scatterplot comparing the Ct values for those 373 miRNAs before and after preamplification is shown in Figure $1 \mathrm{~B}$, and regression analysis demonstrated a significant and linear relation $\left(R^{2}=0.927 ; P<0.001\right)$.

Next, we investigated the effect of profiling miRNA expression by using two different array cards (A and B) per sample. Therefore, UHCA was performed on the normalized miRNA expression data, and the result is shown in Figure 2. The cluster pattern of the miRNAs, represented by the dendrogram in the Y-axis, reveals that the assays allocated at different array cards are not segregated. In addition, miRNA assays directed at different isoforms of the same miRNA and represented on different array cards cluster on terminal branches in approximately $80 \%$ of the cases. These data indicate that variation in miRNA expression related to the incorporation of two separate assays per sample is minor.

Finally, we evaluated the reproducibility of the miRNA assays. Therefore, we analyzed four samples in duplicate 


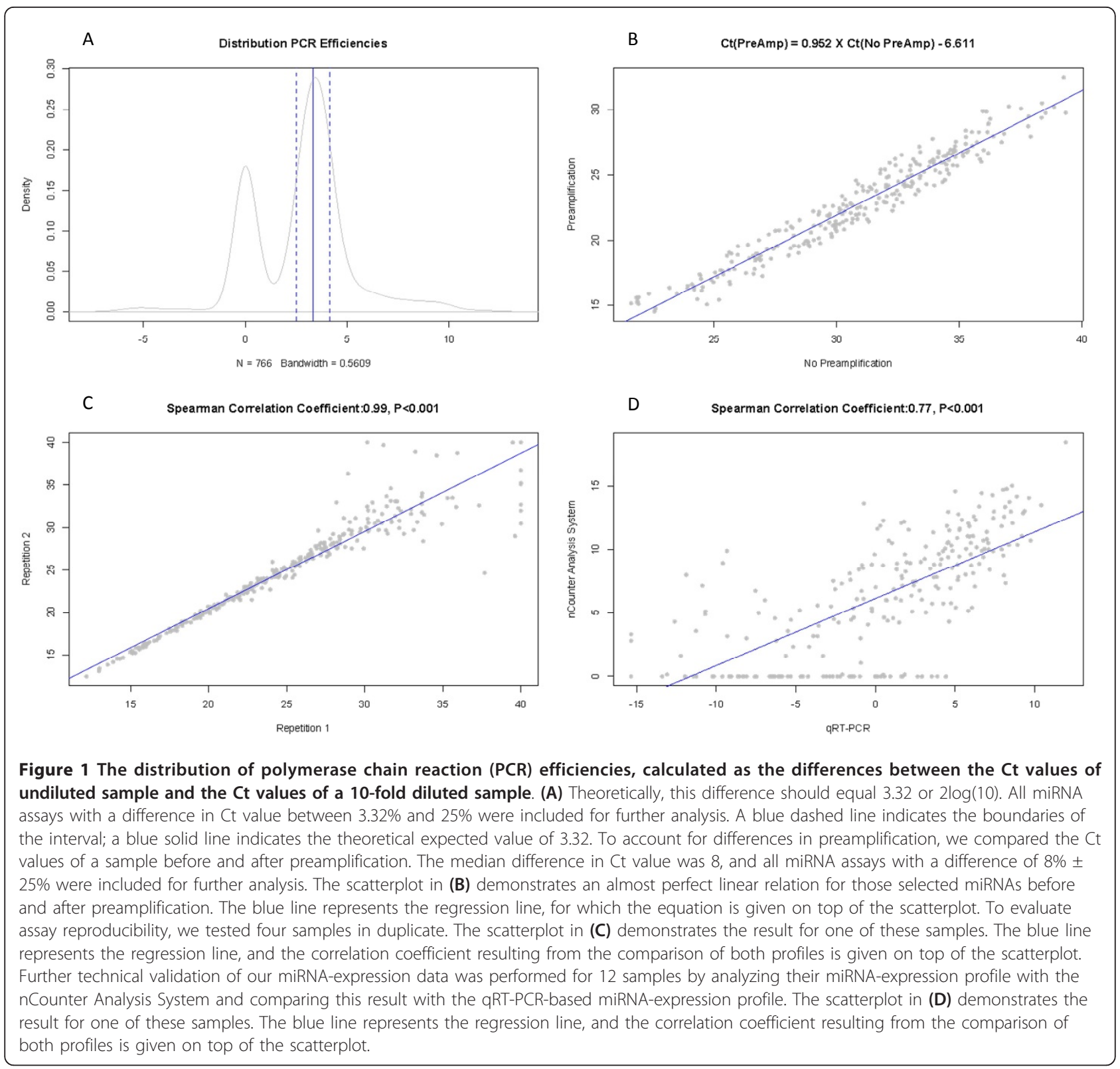

and compared their normalized miRNA expression profiles. A representative scatterplot is show in Figure 1C, and all scatterplots are shown in Additional file 1. Spearman correlation coefficients ranged from 0.98 to 0.99 (all $P$ values $<0.001$ ), indicating good assay reproducibility.

Next, we analyzed the miRNA expression profiles of 12 samples by using the nCounter Analysis System and compared them with the normalized expression data obtained through qRT-PCR. The Spearman correlation coefficients ranged from 0.63 to 0.75 with a median value of 0.72 (all $P$ values $<0.001$ ). Scatterplots for all comparisons are shown in Additional file 2, and a representative scatterplot is provided in Figure 1D.
Overall, our data indicate that technical variation in expression for the panel of 373 miRNAs is minor.

\section{miRNA expression profiling of breast tumor and normal breast samples}

With the miRNA centroids for molecular-subtype classification [14], we classified the 84 breast cancer tissue samples and eight normal tissue samples in our data set. $18,15,15,19$, and 25 samples were classified as Basallike, ErbB2+, Luminal A, Luminal B, and Normal-like, respectively. The classification result is shown under the dendrogram in Figure 2. We observed a significant $(P<$ 0.001) agreement between the miRNA-based molecular subtype classification and the clustering pattern of the 


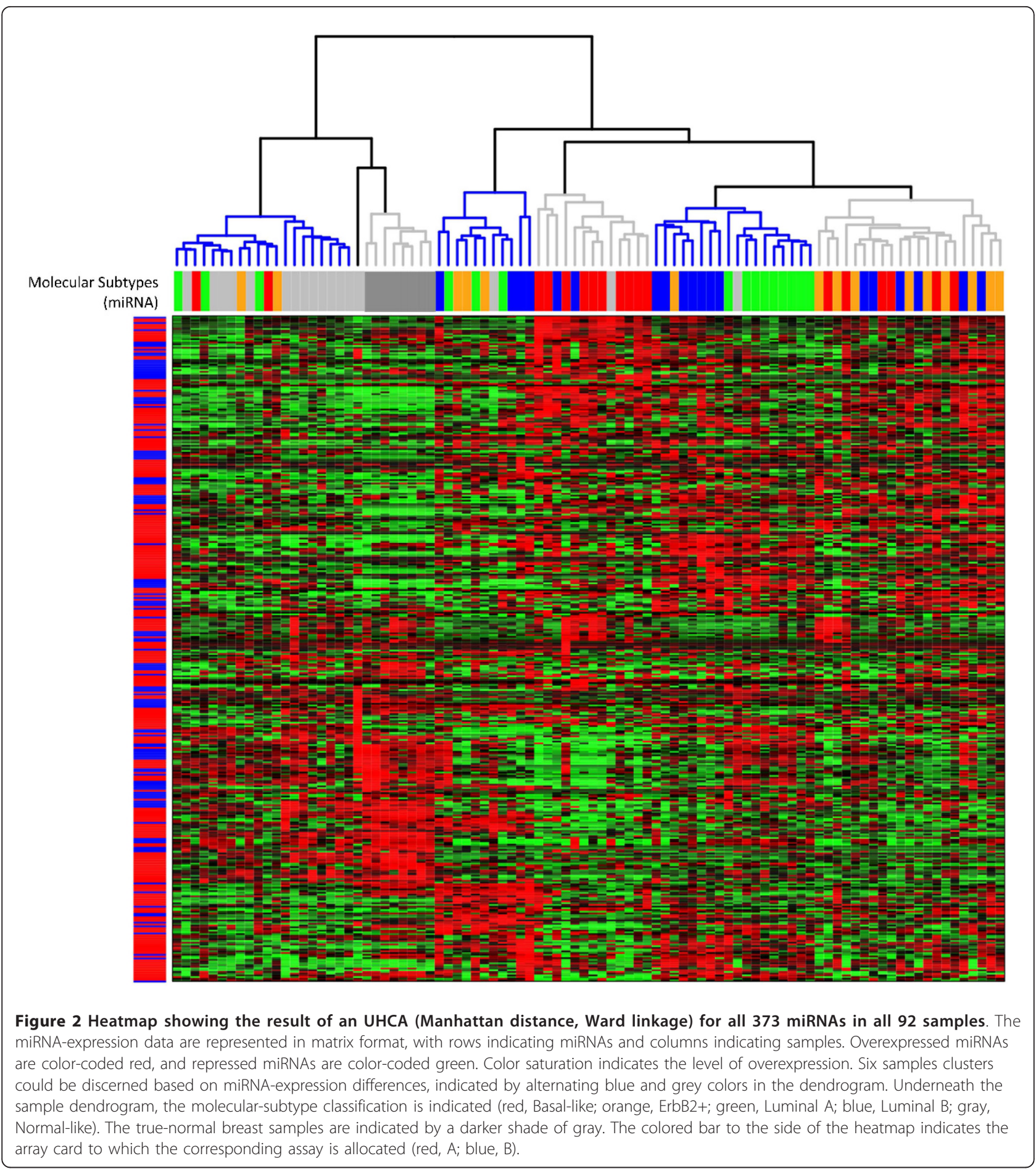

tissue samples after UHCA. Downstream of the first bifurcation, we observe a cluster composed of $76 \%$ of Normal-like samples, which was further divided into two clusters separating the Normal-like tumor samples from the normal breast samples. Further division of the dendrogram yielded a cluster composed of $77 \%$ of Basal-like samples and a cluster enriched for Luminal samples (that is, $89 \%$ of the samples classify as Luminal A or Luminal B). In addition, $60 \%$ of the ErbB2+ samples fell into one sample cluster. Interestingly, downstream of the third bifurcation, we observed a sample cluster not enriched for any of the molecular subtypes (Luminal A, 3; Luminal B, 4; ErbB2+, 3; and Normallike, 1). Given the hierarchy of the dendrogram, this 
sample cluster may well represent a novel miRNA-based breast cancer subtype. Overexpressed miRNAs in this sample group are known for their tumor-suppressive roles in (breast) cancer: the miR-200 family (miR-200a, miR-200b, miR-200c, and miR-141), the let-7 family (let-7a, let-7f, and let-7g), and NF $\kappa \mathrm{B}$-regulating miRNAs (miR-146a and miR-155).

For 66 of 92 samples, Affymetrix mRNA expression profiles were obtained in previous studies [38,39]. Classification of these samples according to the SSP-algorithm yielded an agreement of $66 \%$ with the classification according to the miRNA centroids. Subtype-specific correlation coefficients were compared between the SSP-defined molecular subtypes, and results are shown in Figure 3. For all comparisons, the subtypespecific correlation coefficients obtained by using the miRNA-centroids were significantly elevated in the group of samples classified in the corresponding subtype by using mRNA data (all $P$ values $<0.05$ ). When dichotomizing the Spearman correlation coefficients per subtype relative to 0 , we observed an average classification error rate of $36 \%$, with the highest and lowest classification error rates observed for the Luminal B and ErbB2+ samples (44\% and $27 \%$ ), respectively.

To identify subtype-specific miRNAs, we performed pairwise comparisons between tumor samples grouped by the SSP-defined molecular subtypes. The results are summarized in Table 2. At a P-value cut-off level of
0.01 (maximal FDR of 15\%), we identified 16, 0, 2, 3, and 40 miRNAs specific for the Basal-like, ErbB2+, Luminal A, Luminal B, and Normal-like subtypes, respectively. Comparison of these results with the expression data published by Blenkiron and colleagues [14] revealed remarkably similar expression patterns for several key miRNAs. For example, miR-135b and miR106a are upregulated in Basal-like breast cancers in both studies. Also, miR-100 and miR-145 show comparable expression patterns in both studies, with elevated expression in the Normal-like and Luminal samples. Detailed results are provided in Additional file 3.

Finally, we compared the miRNA expression profiles of tumor samples with the normal breast samples obtained after breast-reductive surgery. As reported earlier, the clustering pattern of the tissue samples (Figure 2) suggests major differences in miRNA expression between the tumor samples and normal breast samples. We identified 59 differentially expressed miRNAs at an FDR less than $1 \%$. The median expression value of these miRNA per sample was significantly higher in normal breast samples (Normal, 1.542; Tumor, 0.024; $P<$ $0.001)$. Data are presented in boxplot format in Figure 4A. The top four miRNAs by fold-change (miR-299-5p, miR-215, miR-411, and miR-452) were selected as potential biomarkers for breast cancer detection (Figure 4B through 4E). With the RmiR-package, we identified $611,715,575$, and 1,863 mRNA targets for the set of

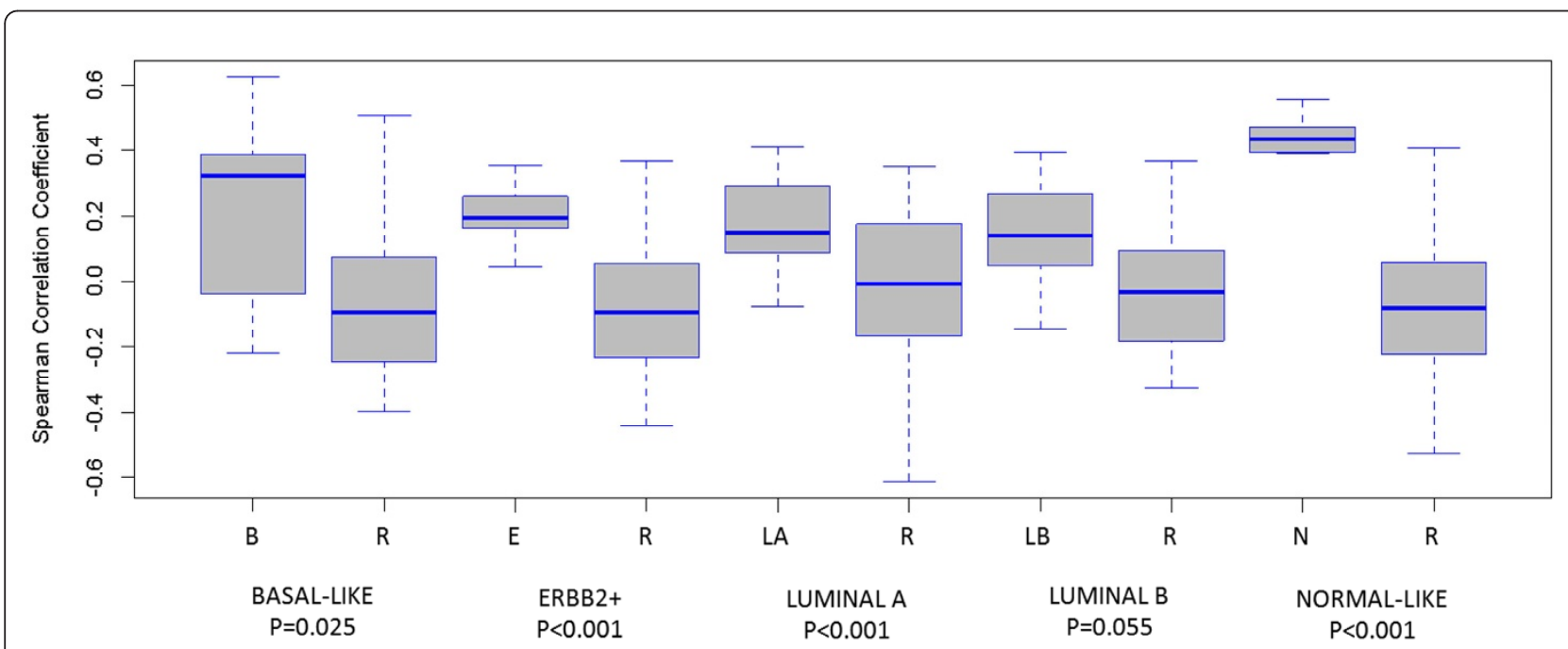

Figure 3 Comparison of the mRNA-based molecular subtype classification by using the SSP method with the miRNA-based classification by using the expression centroids reported by Blenkiron and colleagues. This analysis was performed only for those samples for which Affymetrix mRNA-expression profiles are available $(N=66)$. The SSP-classification is provided in the X-axis $(B, B a s a l ; E, E r b B 2+; L A$, Luminal A; LB, Luminal B; N, Normal-like; and R, Rest). The Spearman correlation coefficients resulting from the miRNA-based molecular subtype classification are indicated in the Y-axis. For each miRNA-based molecular subtype-specific centroid and each sample in our data set, the Spearman correlation coefficients were determined. The molecular subtype-specific correlation coefficients were statistically compared between samples belonging to and not belonging to the SSP-defined molecular subtype of interest. $P$ values are indicated under the corresponding boxplots. 
Table 2 Identification of subtype-specific miRNAs

\begin{tabular}{|c|c|c|c|}
\hline Subtype & Comparator & Number & Common \\
\hline \multirow[t]{4}{*}{ Basal-like } & ErbB2+ & 26 & $\begin{array}{l}\text { hsa-miR-135b\#, hsa-miR-135b, hsa-miR-934, hsa-miR-577, hsa-miR-501-5p, hsa-miR18a\#, hsa-miR-92a, hsa-miR- } \\
\text { 106a, hsa-miR-17, hsa-miR-18b, hsa-miR-18a, hsa-miR-20a, hsa-miR-17\#, hsa-miR-15b\#, hsa-miR-19a, hsa-miR-500 }\end{array}$ \\
\hline & Luminal A & 53 & \\
\hline & Luminal B & 33 & \\
\hline & Normal-like & 90 & \\
\hline \multirow[t]{4}{*}{ ErbB2+ } & Basal-like & 26 & - \\
\hline & Luminal A & 25 & \\
\hline & Luminal B & 14 & \\
\hline & Normal-like & 107 & \\
\hline \multirow{4}{*}{$\begin{array}{l}\text { Luminal } \\
\text { A }\end{array}$} & Basal-like & 53 & hsa-miR-148a, hsa-miR-219-5p \\
\hline & ErbB2+ & 25 & \\
\hline & Luminal B & 15 & \\
\hline & Normal-like & 106 & \\
\hline \multirow{4}{*}{$\begin{array}{l}\text { Luminal } \\
\text { B }\end{array}$} & Basal-like & 33 & hsa-miR-30d\#, hsa-miR-30d, hsa-miR-342-3p \\
\hline & ErbB2+ & 14 & \\
\hline & Luminal A & 15 & \\
\hline & Normal-like & 109 & \\
\hline \multirow[t]{4}{*}{$\begin{array}{l}\text { Normal- } \\
\text { like }\end{array}$} & Basal-like & 90 & $\begin{array}{l}\text { hsa-miR-136\#, hsa-miR-497, hsa-miR-139-5p, hsa-miR-99a\#, hsa-miR-145\#, hsa-miR-195, hsa-miR-143, hsa-miR-145, } \\
\text { hsa-miR-335, hsa-miR-125b-2\#, hsa-miR-139-3p, hsa-miR-7-2\#, hsa-miR-216b, hsa-miR-487b, hsa-miR-100, hsa-miR- } \\
\text { 410, hsa-miR-204, hsa-miR-376a, hsa-miR-99a, hsa-miR-337-3p, hsa-miR-27a\#, hsa-miR-411, hsa-miR-656, hsa-miR- } \\
\text { 495, hsa-miR-551 b\#, hsa-miR-770-5p, hsa-let-7b\#, hsa-miR-378, hsa-miR-215, hsa-miR-127-3p, hsa-let-7c\#, hsa-miR- } \\
\text { 379, hsa-miR-422a, hsa-miR432, hsa-miR-299-5p, hsa-miR-494, hsa-miR-378, hsa-miR-511, hsa-miR-23a\#, hsa-miR- } \\
452\end{array}$ \\
\hline & ErbB2+ & 107 & \\
\hline & Luminal A & 106 & \\
\hline & Luminal B & 109 & \\
\hline
\end{tabular}

$\mathrm{P}$ values, $<0.01$; maximal false discovery rate, $15 \%$.

A.

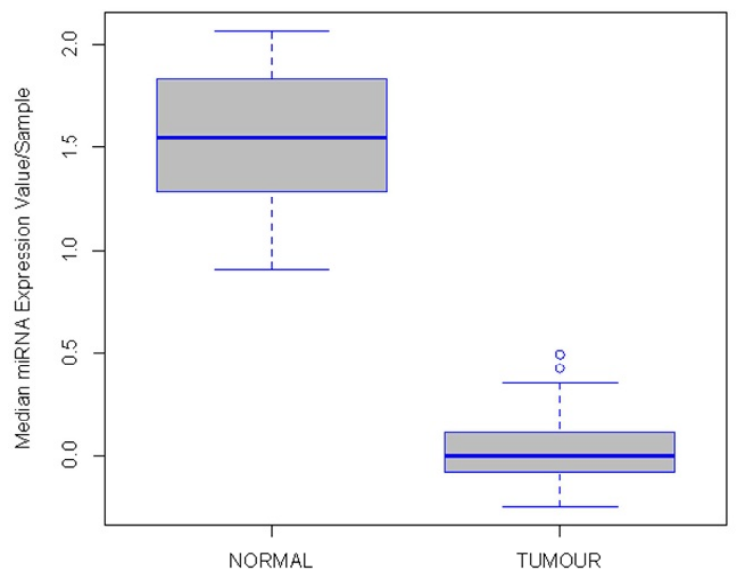

B.

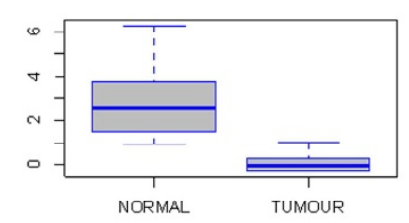

D.

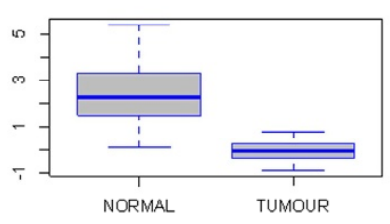

C.

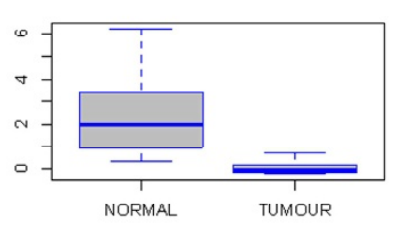

E.

MIR452; FDR $=8.6 \mathrm{e}-10$

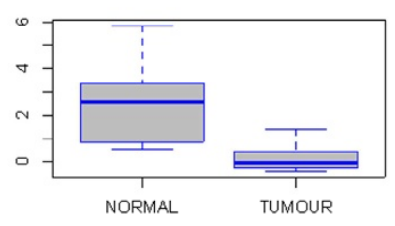

Figure 4 Comparison of normal breast samples with tumor samples. We identified 59 differentially expressed miRNAs between tumor samples and normal breast samples. The median expression of these miRNAs is significantly elevated in normal breast samples, as illustrated by the boxplot (A). The top four miRNAs (miR-215, miR-299-5p, miR-411, and miR-452) with the greatest difference between normal breast samples and breast tumor samples by fold change are depicted in panels $\mathbf{B}$ through $\mathbf{E}$. The corresponding false discovery rate is provided in top of each boxplot. All miRNAs are significantly overexpressed in normal breast samples. 
selected miRNAs, respectively, which were analyzed by using Ingenuity Pathway Analysis. For each miRNA, the five most relevant networks with their most strongly enriched molecular and cellular functions $(P<0.001)$ are listed in Table 3. Comparative analysis of enrichment patterns demonstrated that all miRNAs were involved in the regulation of global oncogenic processes like cell proliferation, cell death, and cellular movement.

\section{Circulating miRNA expression}

To evaluate which blood medium was best suited for investigating miRNA expression, we extracted sRNA molecules from serum, plasma, platelet-rich plasma, whole blood, and PBMCs. A significant increase in sRNA concentration was observed only when comparing the results obtained in whole blood with the results obtained in other media (Kruskal-Wallis, $P<0.001$; Tukey HSD post hoc, all $P$ values $<0.001)$. Results are shown in Additional file 4. As our aim was to measure circulating, tumor-specific miRNA expression, we decided not to perform subsequent analyses on plateletrich plasma, whole blood, or PBMCs because of the possible contamination of host-specific miRNA expression. Given a slight, not significant, increase in sRNA concentration in serum when compared with plasma $(5.3 \mu \mathrm{g} /$ $\mathrm{ml}$ versus $4.2 \mu \mathrm{g} / \mathrm{ml})$, in addition to a more-consistent
sRNA yield in serum $\left(\mathrm{CV}_{\text {serum }}, 50.4 \%\right.$; $\left.\mathrm{CV}_{\text {plasma }}, 94.5 \%\right)$, we decided to use serum to evaluate circulating miRNA expression.

The expression of four miRNAs (miR-299-5p, miR215, miR-411, and miR-452) with the greatest foldchange, when comparing normal breast tissue with breast tumor samples, was analyzed in serum samples from 75 patients with breast cancer and 20 healthy volunteers. We observed higher expression values for all investigated miRNAs, except for miR-452, in serum from healthy volunteers. Significant $(P<0.05)$ values were obtained for miR-299-5p and miR-411, whereas trends $(P<0.10)$ were observed for miR-215 and miR452. Results are shown in Figure 5.

We next compared the expression levels of miR-215, miR-299-5p, miR-411, and miR-452 in serum from patients with metastatic breast cancer receiving treatment (group B), patients with untreated metastatic breast cancer (group C), and healthy volunteers. The group of patients with localized breast cancer was not included in this analysis because of low sample size $(n=$ 4). Results are shown in Figure 5. Kruskal-Wallis testing revealed significant $(P<0.05)$ between-group differences for all miRNAs, except miR-452. Tukey HSD post hoc testing revealed that the lowest expression values were observed in patients with metastatic breast cancer,

Table 3 Biologic and cellular functions of miR-215, miR-299-5p, miR-411, and miR-452

\begin{tabular}{|c|c|c|c|c|}
\hline miRNA & $\begin{array}{l}\text { Network } \\
\text { ID }\end{array}$ & Score & $\begin{array}{l}\text { Number of } \\
\text { genes }\end{array}$ & Top associated functions \\
\hline \multirow[t]{5}{*}{ miR-215 } & 1 & 37 & 28 & Tissue morphology, cell death, drug metabolism \\
\hline & 2 & 20 & 19 & Developmental disorder, gene expression, genetic disorder \\
\hline & 3 & 20 & 19 & $\begin{array}{l}\text { Cellular movement, immune cell trafficking, skeletal and muscular system development and } \\
\text { function }\end{array}$ \\
\hline & 4 & 14 & 15 & RNA damage and repair, cell death, molecular transport \\
\hline & 5 & 13 & 14 & Genetic disorder, cellular assembly and organization, cellular function and maintenance \\
\hline \multirow{5}{*}{$\begin{array}{l}\text { miR-299- } \\
5 p\end{array}$} & 1 & 35 & 29 & Cell-to-cell signaling and interaction, cellular growth and proliferation, tumor morphology \\
\hline & 2 & 24 & 23 & Gene expression, cellular movement, lipid metabolism \\
\hline & 3 & 13 & 16 & Cellular assembly and organization, DNA replication, recombination, and repair, gene expression \\
\hline & 4 & 13 & 16 & Cell morphology, cellular development, protein synthesis \\
\hline & 5 & 11 & 14 & Cell death, renal necrosis/cell death, cellular compromise \\
\hline \multirow[t]{5}{*}{ miR-411 } & 1 & 33 & 26 & Cell death, cell-to-cell signaling and interaction, cell-mediated immune response \\
\hline & 2 & 27 & 23 & $\begin{array}{l}\text { Cardiovascular system development and function, organ development, organismal } \\
\text { development }\end{array}$ \\
\hline & 3 & 17 & 17 & Gene expression, protein synthesis, antimicrobial response \\
\hline & 4 & 14 & 15 & Cell death, cellular growth and proliferation, cellular assembly and organization \\
\hline & 5 & 11 & 13 & Inflammatory response, dermatologic diseases and conditions, inflammatory disease \\
\hline \multirow[t]{5}{*}{ miR-452 } & 1 & 31 & 32 & Gene expression, cellular movement, cell death \\
\hline & 2 & 27 & 30 & $\begin{array}{l}\text { Cell-to-cell signaling and interaction, connective tissue development and function, cell } \\
\text { morphology }\end{array}$ \\
\hline & 3 & 25 & 29 & Cellular growth and proliferation, inflammatory response, cell death \\
\hline & 4 & 25 & 29 & Cellular development, gene expression, nervous system development and function \\
\hline & 5 & 25 & 29 & Cellular growth and proliferation, cardiovascular disease, tissue morphology \\
\hline
\end{tabular}




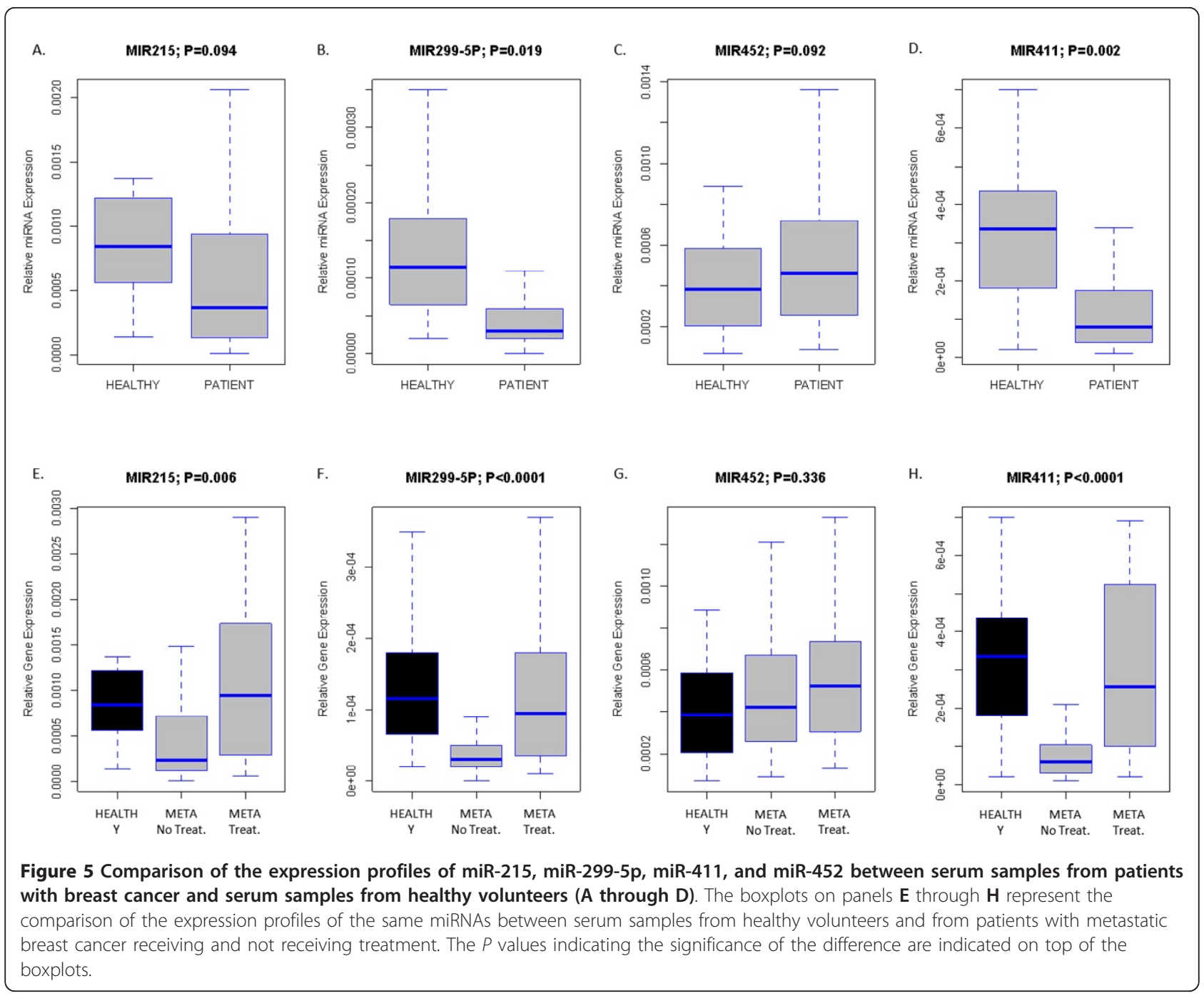

whereas expression levels returned to normal with treatment.

Finally, we compared the expression levels of the circulating miRNAs with clinicopathologic variables, response to treatment evaluated by the RECIST-criteria, presence of circulating tumor markers, and the presence of circulating methylated markers. These analyses were done for all samples except those derived from healthy volunteers. Results are shown in Table 4. Overall, few significant associations were observed. The expression levels for three of four miRNAs (miR-215, miR-299-5p, and miR-411) show a negative association with patient age at diagnosis (all $P$ values $<0.100$ ). Interestingly, all miRNAs have higher expression levels in serum from patients with progressive disease under treatment and for two of four miRNAs (miR-215 and miR-411); these differences were significant $(P<0.050)$. No associations between circulating miRNA expression and the presence of CTCs were observed. For miR-215 and miR-452, we observed positive associations $(P<0.05)$ between their expression levels in serum and the number of methylated genes (any combination of ESR1, APC, and RASSF1A) detected in plasma.

\section{Discussion}

We attempted to identify a panel of deregulated miRNAs in breast cancer and investigated their potential as biomarkers for the detection and staging of breast cancer by using blood-based testing. Before analyzing the miRNA-expression data, we first evaluated the performance of the PCR technology used throughout this study. To reduce the technical variation in our data set, we included only informative miRNAs assays (Ct values smaller than 35 in at least $25 \%$ of the cases) with similar PCR efficiencies and similar differences in $\mathrm{Ct}$ values before and after preamplification. The boundaries for PCR efficiency were defined as described in earlier studies [34], and the boundaries for preamplification 
Table 4 Associations between circulating miRNA expression and clinicopathologic variables

\begin{tabular}{|c|c|c|c|c|c|c|c|c|c|c|}
\hline \multirow[t]{2}{*}{ Group } & \multirow[t]{2}{*}{ Variable } & \multirow[t]{2}{*}{ Test } & \multicolumn{2}{|c|}{ MIR-215 } & \multicolumn{2}{|c|}{ MIR-299-5p } & \multicolumn{2}{|c|}{ MIR-411 } & \multicolumn{2}{|c|}{ MIR-452 } \\
\hline & & & Result & $P$-value & Result & $P$-value & Result & $P$-value & Result & $P$-value \\
\hline \multirow[t]{7}{*}{ Clinicopathologic } & Age & $\begin{array}{l}\text { Spearman } \\
\text { correlation }\end{array}$ & $\begin{array}{l}R= \\
-0.184\end{array}$ & $\begin{array}{l}P= \\
0.113\end{array}$ & $\begin{array}{l}R= \\
-0.455\end{array}$ & $\begin{array}{l}P< \\
0.001\end{array}$ & $\begin{array}{l}R= \\
-0.362\end{array}$ & $\begin{array}{l}P= \\
0.001\end{array}$ & $\begin{array}{l}R= \\
-0.052\end{array}$ & $\begin{array}{l}P= \\
0.657\end{array}$ \\
\hline & $E R^{a}$ & $\begin{array}{l}\text { Mann-Whitney U } \\
\text { test }\end{array}$ & $\begin{array}{l}T= \\
-1.059\end{array}$ & $\begin{array}{l}P= \\
0.295\end{array}$ & $\begin{array}{l}T= \\
0.658\end{array}$ & $\begin{array}{l}P= \\
0.516\end{array}$ & $\begin{array}{l}T= \\
0.305\end{array}$ & $\begin{array}{l}P= \\
0.763\end{array}$ & $\begin{array}{l}T= \\
1.194\end{array}$ & $\begin{array}{l}P= \\
0.244\end{array}$ \\
\hline & $\mathrm{PR}^{\mathrm{a}}$ & $\begin{array}{l}\text { Mann-Whitney U } \\
\text { test }\end{array}$ & $\begin{array}{l}T= \\
-0.672\end{array}$ & $\begin{array}{l}P= \\
0.504\end{array}$ & $\begin{array}{l}T= \\
-0.193\end{array}$ & $\begin{array}{l}P= \\
0.848\end{array}$ & $\begin{array}{l}T= \\
-0.645\end{array}$ & $\begin{array}{l}P= \\
0.521\end{array}$ & $\begin{array}{l}T= \\
1.519\end{array}$ & $\begin{array}{l}P= \\
0.136\end{array}$ \\
\hline & $H R^{a}$ & $\begin{array}{l}\text { Mann-Whitney U } \\
\text { test }\end{array}$ & $\begin{array}{l}T= \\
-1.233\end{array}$ & $\begin{array}{l}P= \\
0.225\end{array}$ & $\begin{array}{l}T= \\
0.632\end{array}$ & $\begin{array}{l}P= \\
0.534\end{array}$ & $\begin{array}{l}T= \\
0.299\end{array}$ & $\begin{array}{l}P= \\
0.767\end{array}$ & $\begin{array}{l}T= \\
1.015\end{array}$ & $\begin{array}{l}P= \\
0.321\end{array}$ \\
\hline & $\mathrm{ERBB}^{\mathrm{a}}$ & $\begin{array}{l}\text { Mann-Whitney U } \\
\text { test }\end{array}$ & $\begin{array}{l}T= \\
0.051\end{array}$ & $\begin{array}{l}P= \\
0.960\end{array}$ & $\begin{array}{l}T= \\
-1.237\end{array}$ & $\begin{array}{l}P= \\
0.222\end{array}$ & $\begin{array}{l}T= \\
-1.594\end{array}$ & $\begin{array}{l}P= \\
0.120\end{array}$ & $\begin{array}{l}T= \\
-0.841\end{array}$ & $\begin{array}{l}P= \\
0.406\end{array}$ \\
\hline & $\mathrm{TNBC}^{\mathrm{a}}$ & $\begin{array}{l}\text { Mann-Whitney U } \\
\text { test }\end{array}$ & $\begin{array}{l}T= \\
-0.399\end{array}$ & $\begin{array}{l}P= \\
0.699\end{array}$ & $\begin{array}{l}T= \\
-0.310\end{array}$ & $\begin{array}{l}P= \\
0.765\end{array}$ & $\begin{array}{l}T= \\
-0.365\end{array}$ & $\begin{array}{l}P= \\
0.725\end{array}$ & $\begin{array}{l}T= \\
0.281\end{array}$ & $\begin{array}{l}P= \\
0.785\end{array}$ \\
\hline & $P 53^{\mathrm{a}}$ & $\begin{array}{l}\text { Mann-Whitney U } \\
\text { test }\end{array}$ & $\begin{array}{l}T= \\
0.256\end{array}$ & $\begin{array}{l}P= \\
0.800\end{array}$ & $\begin{array}{l}T= \\
1.041\end{array}$ & $\begin{array}{l}P= \\
0.304\end{array}$ & $\begin{array}{l}T= \\
1.617\end{array}$ & $\begin{array}{l}P= \\
0.113\end{array}$ & $\begin{array}{l}T= \\
-0.953\end{array}$ & $\begin{array}{l}P= \\
0.347\end{array}$ \\
\hline RECIST & Progressive disease ${ }^{a}$ & $\begin{array}{l}\text { Mann-Whitney U } \\
\text { test }\end{array}$ & $\begin{array}{l}T= \\
-2.404\end{array}$ & $\begin{array}{l}P= \\
0.019\end{array}$ & $\begin{array}{l}T= \\
-0.998\end{array}$ & $\begin{array}{l}P= \\
0.322\end{array}$ & $\begin{array}{l}T= \\
-2.488\end{array}$ & $\begin{array}{l}P= \\
0.016\end{array}$ & $\begin{array}{l}T= \\
-0.399\end{array}$ & $\begin{array}{l}P= \\
0.691\end{array}$ \\
\hline \multirow[t]{5}{*}{$\begin{array}{l}\text { Circulating } \\
\text { markers }\end{array}$} & Number CTCs & $\begin{array}{l}\text { Spearman } \\
\text { correlation }\end{array}$ & $\begin{array}{l}R= \\
0.056\end{array}$ & $\begin{array}{l}P= \\
0.635\end{array}$ & $\begin{array}{l}R= \\
-0.026\end{array}$ & $\begin{array}{l}P= \\
0.826\end{array}$ & $\begin{array}{l}R= \\
0.053\end{array}$ & $\begin{array}{l}P= \\
0.655\end{array}$ & $\begin{array}{l}R= \\
-0.094\end{array}$ & $\begin{array}{l}P= \\
0.424\end{array}$ \\
\hline & ADNAGen $^{a}$ & $\begin{array}{l}\text { Mann-Whitney U } \\
\text { test }\end{array}$ & $\begin{array}{l}T= \\
-0.534\end{array}$ & $\begin{array}{l}P= \\
0.596\end{array}$ & $\begin{array}{l}T= \\
1.789\end{array}$ & $\begin{array}{l}P= \\
0.078\end{array}$ & $\begin{array}{l}T= \\
0.782\end{array}$ & $\begin{array}{l}P= \\
0.437\end{array}$ & $\begin{array}{l}T= \\
-2.144\end{array}$ & $\begin{array}{l}P= \\
0.041\end{array}$ \\
\hline & $\begin{array}{l}\text { Mammaglobin } \\
\text { expression }\end{array}$ & $\begin{array}{l}\text { Spearman } \\
\text { correlation }\end{array}$ & $\begin{array}{l}R= \\
0.047\end{array}$ & $\begin{array}{l}P= \\
0.697\end{array}$ & $\begin{array}{l}R= \\
0.005\end{array}$ & $\begin{array}{l}P= \\
0.969\end{array}$ & $\begin{array}{l}R= \\
0.086\end{array}$ & $\begin{array}{l}P= \\
0.474\end{array}$ & $\begin{array}{l}R= \\
-0.107\end{array}$ & $\begin{array}{l}P= \\
0.374\end{array}$ \\
\hline & $\begin{array}{l}\text { Cytokeratin } 19 \\
\text { expression }\end{array}$ & $\begin{array}{l}\text { Spearman } \\
\text { correlation }\end{array}$ & $\begin{array}{l}R= \\
0.191\end{array}$ & $\begin{array}{l}P= \\
0.110\end{array}$ & $\begin{array}{l}R= \\
-0.099\end{array}$ & $\begin{array}{l}P= \\
0.409\end{array}$ & $\begin{array}{l}R= \\
-0.010\end{array}$ & $\begin{array}{l}P= \\
0.933\end{array}$ & $\begin{array}{l}R= \\
0.004\end{array}$ & $\begin{array}{l}P= \\
0.968\end{array}$ \\
\hline & $\begin{array}{l}\text { Plasma DNA } \\
\text { concentration }\end{array}$ & $\begin{array}{l}\text { Spearman } \\
\text { correlation }\end{array}$ & $\begin{array}{l}R= \\
0.200\end{array}$ & $\begin{array}{l}P= \\
0.085\end{array}$ & $\begin{array}{l}R= \\
-0.100\end{array}$ & $\begin{array}{l}P= \\
0.392\end{array}$ & $\begin{array}{l}R= \\
-0.043\end{array}$ & $\begin{array}{l}P= \\
0.712\end{array}$ & $\begin{array}{l}R= \\
0.085\end{array}$ & $\begin{array}{l}P= \\
0.467\end{array}$ \\
\hline \multirow[t]{5}{*}{$\begin{array}{l}\text { Methylated } \\
\text { markers }\end{array}$} & RASSF1A & $\begin{array}{l}\text { Spearman } \\
\text { correlation }\end{array}$ & $\begin{array}{l}R= \\
-0.129\end{array}$ & $\begin{array}{l}P= \\
0.271\end{array}$ & $\begin{array}{l}R= \\
-0.198\end{array}$ & $\begin{array}{l}P= \\
0.089\end{array}$ & $\begin{array}{l}R= \\
-0.189\end{array}$ & $\begin{array}{l}P= \\
0.104\end{array}$ & $\begin{array}{l}R= \\
0.025\end{array}$ & $\begin{array}{l}P= \\
0.829\end{array}$ \\
\hline & APC & $\begin{array}{l}\text { Spearman } \\
\text { correlation }\end{array}$ & $\begin{array}{l}R= \\
-0.144\end{array}$ & $\begin{array}{l}P= \\
0.217\end{array}$ & $\begin{array}{l}R= \\
-0.134\end{array}$ & $\begin{array}{l}P= \\
0.253\end{array}$ & $\begin{array}{l}R= \\
-0.114\end{array}$ & $\begin{array}{l}P= \\
0.332\end{array}$ & $\begin{array}{l}R= \\
-0.010\end{array}$ & $\begin{array}{l}P= \\
0.930\end{array}$ \\
\hline & ESR1 & $\begin{array}{l}\text { Spearman } \\
\text { correlation }\end{array}$ & $\begin{array}{l}R= \\
0.148\end{array}$ & $\begin{array}{l}P= \\
0.205\end{array}$ & $\begin{array}{l}R= \\
0.001\end{array}$ & $\begin{array}{l}P= \\
0.997\end{array}$ & $\begin{array}{l}R= \\
0.086\end{array}$ & $\begin{array}{l}P= \\
0.461\end{array}$ & $\begin{array}{l}R= \\
0.252\end{array}$ & $\begin{array}{l}P= \\
0.029\end{array}$ \\
\hline & $\begin{array}{l}\text { Number methylated } \\
\text { genes }\end{array}$ & $\begin{array}{l}\text { Spearman } \\
\text { correlation }\end{array}$ & $\begin{array}{l}R= \\
0.250\end{array}$ & $\begin{array}{l}P= \\
0.031\end{array}$ & $\begin{array}{l}R= \\
-0.159\end{array}$ & $\begin{array}{l}P= \\
0.172\end{array}$ & $\begin{array}{l}R= \\
-0.039\end{array}$ & $\begin{array}{l}P= \\
0.740\end{array}$ & $\begin{array}{l}R= \\
0.262\end{array}$ & $\begin{array}{l}P= \\
0.023\end{array}$ \\
\hline & Methylation status ${ }^{\mathrm{a}}$ & $\begin{array}{l}\text { Mann-Whitney U } \\
\text { test }\end{array}$ & $\begin{array}{l}T= \\
-1.583\end{array}$ & $\begin{array}{l}P= \\
0.118\end{array}$ & $\begin{array}{l}T= \\
1.456\end{array}$ & $\begin{array}{l}P= \\
0.152\end{array}$ & $\begin{array}{l}T= \\
0.538\end{array}$ & $\begin{array}{l}P= \\
0.593\end{array}$ & $\begin{array}{l}T= \\
-1.270\end{array}$ & $\begin{array}{l}P= \\
0.208\end{array}$ \\
\hline
\end{tabular}

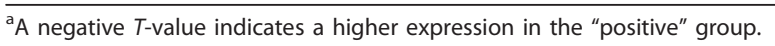

efficiency were set alike. The expression data recorded by the final set of 373 selected miRNAs proved to be reproducible, and no between-array card difference was observed. Moreover, we noticed an above-moderate agreement between the qRT-PCR-based miRNA profiles of 12 samples with the miRNA profiles measured by using the nCounter Analysis System.

This is important for two reasons. First, the nCounter Analysis System incorporates only one enzymatic step (that is, a ligase treatment for attachment of the reporter tags) in its workflow and is therefore less prone to technical bias than is the PCR-based protocol that incorporates three enzymatic steps.

A second reason for comparing the miRNA expression profiles by using alternative profiling techniques is related to the fact that good normalization procedures for miRNA expression data are currently still lacking. The qRT-PCR-based miRNA-expression data in this study were normalized relative to the mean expression value of all miRNAs per sample, as proposed by Mestdagh et al. [35]. However, we think that this normalization procedure might have a major drawback because of the role of DICER1, a miRNA-preprocessing enzyme, in breast cancer. Recent reports have shown that the expression of DICER1 is different across the different molecular subtypes [14,40-42]. As DICER1 is involved in cleaving the precursor miRNAs into mature miRNAs, variation in DICER1 expression might result in altered turnover rates of the precursor miRNAs and, hence, higher concentrations of mature miRNAs in those tumor samples with higher DICER1 expression. Therefore, we reason that the mean miRNA-expression levels 
can vary depending on DICER1 expression and that normalization relative to the mean miRNA-expression level might obscure between-sample differences, particularly in breast cancer. The alternative approach would be to use the reference miRNAs provided on the array cards or miR-16, which is often suggested as reference miRNA. However, the CVs for these reference miRNAs were about threefold higher than the $\mathrm{CV}$ of the mean miRNA expression level per sample. In addition, about $20 \%$ of the miRNA assays on both array cards yielded more-robust expression data (data not shown).

Therefore, in spite of our previously raised concerns, we decided to normalize our expression data relative to the mean $\mathrm{Ct}$ value per sample and compare the results with the data obtained by using nCounter Analysis System, which uses a panel of five mRNA assays (RPLPO, RPL19, ACTB, B2M, and GAPDH) for data normalization. The above-moderate agreement between the miRNA-expression data obtained by using both profiling techniques lends credit to the biologic validity of our qRT-PCR-based miRNA-expression profiles.

Further evidence that the applied normalization procedure did not obscure molecular subtype-specific differences is derived from the UHCA, which showed that the molecular subtypes govern global themes in our miRNA expression data set. Also, the miRNA-based molecular subtype classification is in agreement with the classification resulting from the application of a morevalidated algorithm on mRNA data (SSP) [37]. For example, the comparison of the miRNA-based expression profile of SSP-defined Basal-like breast tumors with the miRNA-based expression centroid for Basal-like breast cancer results in more-elevated Spearman correlation coefficients than when compared with the results obtained for non-Basal-like breast tumor samples. Although the classification error rate was substantial, we must keep in mind that the miRNA-based expression centroids reported by Blenkiron and colleagues [14] are based on a limited series of samples. Therefore, it is arguable that the expression centroids are not very stable, which affects the classification accuracy. When performing a supervised analysis, we were able to identify sets of specific miRNAs for each molecular subtype, except for the ErbB2+ breast tumor samples. Overall, our results are in line with previously reported data [14,43-45], except for the results with respect to the ErbB2+ subtype, for which an miRNA signature has been defined in the past [45]. Of note is the concordant overexpression of miRNAs belonging to the polycistronic miR-17-92 cluster (miR-17, miR-18a, miR-19a, miR20a, and miR-92) and its paralogs (miR-18b and miR106a) in Basal-like breast tumors. The miR-17-92 cluster is known to downregulate $\mathrm{ER} \alpha$ in a MYC-dependent manner and inhibits the protein translation of AIB1, an
ER $\alpha$ transcriptional coactivator [46]. Also, the miR-1792 cluster is known to regulate cell migration, invasion, and metastasis in breast cancer by regulating ROCK [47] and the HBP1/ $\beta$-catenin pathway [48].

Although the sample-clustering pattern based on the expression of 373 miRNAs demonstrated that the global themes in our expression data set are related to the presence of the classic molecular subtypes in breast cancer, we did identify one sample cluster without any connection to the classic molecular subtypes. This sample cluster originated early in the dendrogram, indicative of a specific miRNA-expression profile. Indeed, the heatmap did reveal an miRNA cluster, including members of the miR-200 family, members of the let-7 family, and $\mathrm{NF} \kappa \mathrm{B}$-regulating miRNAs [49], that is overexpressed in this group of tumor samples, at a level exceeding the expression level observed in the Luminal-like sample cluster. The latter observation is at least remarkable, as all these miRNA families are known to inhibit stem cellspecific pathways, epithelial-to-mesenchymal transition, cell proliferation, and other global oncogenic processes [16,50-53]. Hence, their overexpression would induce a more-differentiated, less-proliferative, less-mesenchymal, and less-migratory/invasive cell phenotype. The presence of this tumor sample cluster with its particular molecular characteristics warrants further investigation. When focusing on the Normal-like samples, a clear and distinct miRNA profile was observed. In addition, the true normal breast samples constituted a coherent group inside the cluster of the Normal-like samples, suggesting vast differences in miRNA expression between tumor samples and normal breast samples. Indeed, supervised analysis revealed high numbers of differentially expressed miRNAs with nominal (uncorrected) $P$ values less than 0.05 .

The huge difference in miRNA expression between normal and tumor samples underlines the important role of miRNA deregulation in the development of breast cancer. After correction for false discovery, we observed that the majority of the differentially expressed miRNAs have attenuated expression levels in the tumor samples. The global repression of miRNAs in cancerous tissue relative to normal tissue has been reported previously and suggests that most miRNAs have a tumorsuppressive function [13]. This view is corroborated by reports on the cellular functions of the top four (miR215, miR-299-5p, miR-411, and miR-452) differentially expressed miRNAs by fold-change. Song et al. [54] demonstrated that miR-215 overexpression in a colon cancer cell line reduced the proliferation rate and led to improved cell-cycle control, probably due to an increased expression of the cell-cycle control genes $p 53$ and $p 21$. Duan et al. [55] showed that miR-299-5p expression increased downstream of the tumor 
suppressor PRDM5 in HEK293 cells. In contrast, Fang et al. [56] showed that $S O X 2$, a gene with tumor-promoting activity involved in cell proliferation and colony formation of LN229 glioblastoma multiforme cells, represses miR-452. The evidence for a role of miR-411 as tumor suppressor is less clear, but this miRNA is located at the 14q32.31 locus, which is known to harbor many tumor-suppressive miRNAs [57]. The biologic processes regulated by miR-215, miR-299-5p, miR-411, and miR-452, identified through the analysis of their respective target-gene lists, are in line with their role in maintaining cellular homeostasis.

Because of the marked overexpression of miR-215, miR-299-5p, miR-411, and miR-452 in normal breast samples, in addition to the fact that miRNAs have a proven stability in blood samples [29], we hypothesized that this panel of miRNAs might be suitable for the detection of breast cancer by using blood-borne testing. The reason for using serum samples for this purpose is twofold. First, we argued that miRNA-expression profiles in whole blood, platelet-rich plasma, and PBMCs would be dominated by host miRNA expression, and therefore would be less suitable for the detection of tumor-specific miRNA expression. Conversely, reports have shown that miRNA expression is also detectable in serum and plasma samples from healthy donors [58]. Second, we noticed a slightly higher and more consistent sRNA yield in serum as compared with plasma. When evaluating the relative expression profiles of miR215, miR-299-5p, miR-411, and miR-452 in serum samples from patients with breast cancer and healthy volunteers, we recorded comparable expression profiles in tissue and blood samples, except for miR-452. Of note, when comparing absolute CT values, the expression differences between samples from patients with breast cancer and healthy volunteers were maintained, however, at a higher fold-change level. In addition, we observed that the reduction of miRNA expression was particularly obvious in serum samples from patients with untreated metastatic breast cancer, whereas the expression profiles "normalized" with treatment.

No associations between blood-borne miRNA expression in serum samples from patients with breast cancer and the classical clinicopathologic variables were observed, except for the patient's age at diagnosis. However, this should not be surprising, as our miRNA panel was not selected to make this distinction. Of note is the lack of associations between circulating miRNA expression and the presence of CTCs, measured by three alternative techniques. This observation suggests that recorded serum miRNA profiles are not CTC derived and that the mechanisms responsible for the release of miRNAs in the circulation are unrelated to the extravasation of tumor cells. Indeed, several reports have suggested that miRNAs are selectively released in the bloodstream by tumor cells either via exosomes or attached to lipoprotein complexes or within a functional RISC complex [59-63]. These mechanisms of secretion offer an explanation for the marked stability of miRNAs in the blood stream, due to shielding of the associated miRNAs from RNAse-activity. In addition, miRNAs secreted as such are functionally active and have been found to regulate gene expression in target cells, thereby providing alternative ways of cell-cell communication. This opens the possibility that miRNAs, secreted by tumor cells, evoke a response in host cells altering their expression profile, which explains how subtle differences in tumor-specific expression are measurable in a background of nontumorigenic expression. More specific in the context of our results, one could envision that tumor-driving miRNAs, secreted by tumor cells, affect the expression profile of host cells, which is reflected in the serum profile of breast cancer patients and explains the observed decrease in miRNA expression.

\section{Conclusions}

The present data provide a technologically validated framework to elaborate on the study of miRNA-deregulation in the development of breast cancer. We potentially identified a novel subgroup of breast tumors with elevated expression of tumor-suppressive miRNAs, and we showed that miRNAs can be used as blood-borne biomarkers for detection and staging of breast cancer. The identification of several molecular subtype-specific miRNAs in this study also suggests that blood tests directed at the molecular subtypes can be developed in the future. However, to do so, a larger repository of molecular subtype-specific miRNA expression is required.

\section{Additional material}

Additional file 1: To evaluate assay reproducibility, we tested four samples in duplicate. The scatterplots demonstrate the result for these samples. The blue line represents the regression line and the correlation coefficients, and corresponding $P$ values are given on top of the scatterplot.

Additional file 2: To perform a technical validation of our miRNAexpression data, we analyzed 12 samples by using the nCounter Analysis System and compared these results with the qRT-PCRbased miRNA expression profiles. The scatterplots illustrate the result of this comparison. The correlation coefficients for each comparison are reported on top of the scatterplots.

Additional file 3: Boxplots showing the comparison of the miRNAexpression profiles of four selected miRNAs (miR-135b, miR-106a, miR-100, and miR-145) between tumor samples grouped by their SSP-defined molecular subtype. The top row represents two miRNAs overexpressed in the Basal-like samples; the bottom row represents two miRNAs overexpressed in Normal-like samples. The color scheme under each boxplot is adopted from the article by Blenkiron and colleagues and depicts the expression of the corresponding miRNAs according to the SSP-defined molecular subtypes, as reported in their study. Red indicates overexpression, and grey indicates repression. As can be 
observed, the variation in miRNA expression across the SSP-defined molecular subtypes is in good agreement in both studies.

Additional file 4: Boxplot illustrating the sRNA yields extracted from five different peripheral blood media. The $X$-axis depicts the different analyzed media (from left to right: serum, plasma, platelet-rich plasma, peripheral blood mononuclear cells (PBMCs), and whole blood); the Yaxis depicts the sRNA concentration. The sRNA yields are most pronounced in whole blood followed by the PBMC fraction. For serum, plasma, and platelet-rich plasma, the results are comparable, although the sRNA yield is slightly higher in serum.

\section{Abbreviations}

CTC: circulating tumor cell; FDR: false discovery rate; miRNA: microRNA; PBMC: peripheral blood mononuclear cell; RECIST: response-evaluation criteria in solid tumors; RISC: RNA-induced silencing complex; SRNA: small RNA; SSP: single sample predictor; UHCA: unsupervised hierarchical cluster analysis.

\section{Author details}

'Department of Oncology, University Hospitals Leuven and Catholic University Leuven, Herestraat 49, Leuven, B3000 Belgium. ${ }^{2}$ Translational Cancer Research Unit, GZA Hospitals St-Augustinus, Oosterveldlaan 24, Antwerp, B2610 Belgium. ${ }^{3}$ Radboud University Nijmegen Medical Center, Postbus 9101, Nijmegen, 6500 HB, The Netherlands. ${ }^{4}$ Department of Medical Oncology, University Hospital Antwerp, Wilrijkstraat 10, B2650, Antwerp, Belgium.

\section{Authors' contributions}

EVS, MCAW, and IVDA acquired all data. IVDA and SJVL performed data analysis. EVS, MCAW, IVDA, and SVL assisted in data interpretation. IVDA, SJVL, PBV, and LD contributed to the conception and design of the study. EVS, MCAW, IVDA, and SVL were involved in drafting the manuscript. All authors were involved in revising the manuscript critically for important intellectual content. All authors gave final approval of the version to be published.

\section{Competing interests}

The authors declare that they have no competing interests.

Received: 4 October 2011 Revised: 21 November 2011

Accepted: 21 February 2012 Published: 21 February 2012

\section{References}

1. Ambros V: MicroRNA pathways in flies and worms: growth, death, fat, stress, and timing. Cell 2003, 113:673-676.

2. Bartel DP: MicroRNAs: genomics, biogenesis, mechanism, and function. Cell 2004, 116:281-297.

3. He L, Hannon GJ: MicroRNAs: small RNAs with a big role in gene regulation. Nat Rev Genet 2004, 5:522-531

4. Lim LP, Lau NC, Garrett-Engele P, Grimson A, Schelter JM, Castle J, Bartel DP, Linsley PS, Johnson JM: Microarray analysis shows that some microRNAs downregulate large numbers of target mRNAs. Nature 2005, 433:769-773.

5. Sevignani C, Calin GA, Siracusa LD, Croce CM: Mammalian microRNAs: a small world for fine-tuning gene expression. Mamm Genome 2006, 17:189-202.

6. Zamore PD, Haley B: Ribo-gnome: the big world of small RNAs. Science 2005, 309:1519-1524.

7. Lewis BP, Burge CB, Bartel DP: Conserved seed pairing, often flanked by adenosines, indicates that thousands of human genes are microRNA targets. Cell 2005, 120:15-20.

8. Erson AE, Petty EM: MicroRNAs in development and disease. Clin Genet 2008, 74:296-306.

9. Cheng AM, Byrom MW, Shelton J, Ford LP: Antisense inhibition of human miRNAs and indications for an involvement of miRNA in cell growth and apoptosis. Nucleic Acids Res 2005, 33:1290-1297.

10. Xu P, Guo M, Hay BA: MicroRNAs and the regulation of cell death. Trends Genet 2004, 20:617-624.
11. Karp $X$, Ambros V: Developmental biology: encountering microRNAs in cell fate signaling. Science 2005, 310:1288-1289.

12. Pillai RS: MicroRNA function: multiple mechanisms for a tiny RNA? RNA 2005, 11:1753-1761.

13. Lu J, Getz G, Miska EA, Alvarez-Saavedra E, Lamb J, Peck D, SweetCordero A, Ebert BL, Mak RH, Ferrando AA, Downing JR, Jacks T, Horvitz HR, Golub TR: MicroRNA expression profiles classify human cancers. Nature 2005, 435:834-838

14. Blenkiron C, Goldstein LD, Thorne NP, Spiteri I, Chin S-F, Dunning MJ, Barbosa-Morais NL, Teschendorff AE, Green AR, Ellis IO, Tavaré S, Caldas C, Miska EA: MicroRNA expression profiling of human breast cancer identifies new markers of tumor subtype. Genome Biol 2007, 8:R214

15. Baffa R, Fassan M, Volinia S, O'Hara B, Liu C, Palazzo JP, Gardiman M, Rugge M, Gomella LG, Croce CM, Rosenberg A: MicroRNA expression profiling of human metastatic cancers identifies cancer gene targets. J Pathol 2009, 219:214-221.

16. Volinia S, Calin GA, Liu CG, Ambs S, Cimmino A, Petrocca F, Visone R, lorio M, Roldo C, Ferracin M, Prueitt RL, Yanaihara N, Lanza G, Scarpa A, Vecchione A, Negrini M, Harris CC, Croce CM: A microRNA expression signature of human solid tumors defines cancer gene targets. Proc Natl Acad Sci USA 2006, 103:2257-2261.

17. Martello G, Rosato A, Ferrari F, Manfrin A, Cordenonsi M, Dupont S, Enzo E, Guzzardo V, Rondina M, Spruce T, Parenti AR, Daidone MG, Bicciato S, Piccolo S: A microRNA targeting dicer for metastasis control. Cell 2010, 141:1195-1207.

18. Ma L, Teruya-Feldstein J, Weinberg RA: Tumour invasion and metastasis initiated by microRNA-10b in breast cancer. Nature 2007, 449:682-688.

19. Johnson SM, Grosshans H, Shingara J, Byrom M, Jarvis R, Cheng A, Labourier E, Reinert KL, Brown D, Slack FJ: RAS is regulated by the let-7 microRNA family. Cell 2005, 120:635-647.

20. Fabbri M, Garzon R, Cimmino A, Liu Z, Zanesi N, Callegari E, Liu S, Alder H, Costinean S, Fernandez-Cymering C, Volinia S, Guler G, Morrison CD, Chan KK, Marcucci G, Calin GA, Huebner K, Croce CM: MicroRNA-29 family reverts aberrant methylation in lung cancer by targeting DNA methyltransferases 3A and 3B. Proc Natl Acad Sci USA 2007, 104:15805-15810.

21. Bombonati A, Sgroi DC: The molecular pathology of breast cancer progression. J Pathol 2011, 223:307-317.

22. Perou CM, Sørlie T, Eisen MB, Van De Rijn M, Jeffrey SS, Rees CA, Pollack JR, Ross DT, Johnsen $H$, Akslen LA, Fluge O, Pergamenschikov A, Williams $C$ Zhu SX, Lønning PE, Børresen-Dale AL, Brown PO, Botstein D: Molecular portraits of human breast tumours. Nature 2000, 406:747-752.

23. Prat A, Parker JS, Karginova O, Fan C, Livasy C, Herschkowitz JI, He X, Perou CM: Phenotypic and molecular characterization of the claudin-low intrinsic subtype of breast cancer. Breast Cancer Res 2010, 12:R68.

24. Gatza ML, Lucas JE, Barry WT, Kim JW, Wang Q, Crawford MD, Datto MB, Kelley M, Mathey-Prevot B, Potti A, Nevins JR: A pathway-based classification of human breast cancer. Proc Natl Acad Sci USA 2010, 107:6994-6999.

25. Iorio MV, Ferracin M, Liu CG, Veronese A, Spizzo R, Sabbioni S, Magri E, Pedriali M, Fabbri M, Campiglio M, Ménard S, Palazzo JP, Rosenberg A, Musiani P, Volinia S, Nenci I, Calin GA, Querzoli P, Negrini M, Croce C: MicroRNA gene expression deregulation in human breast cancer. Cancer Res 2005, 65:7065-7070.

26. Xi Y, Nakajima G, Gavin E, Morris CG, Kudo K, Hayashi K, Ju J: Systematic analysis of microRNA expression of RNA extracted from fresh frozen and formalin-fixed paraffin-embedded samples. RNA 2007, 13:1668-1674.

27. Li J, Smyth P, Flavin R, Cahill S, Denning K, Aherne S, Guenther SM, O'Leary JJ, Sheils O: Comparison of miRNA expression patterns using total RNA extracted from matched samples of formalin-fixed paraffinembedded (FFPE) cells and snap frozen cells. BMC Biotechnol 2007, 7:1-6.

28. Gilad S, Meiri E, Yogev Y, Benjamin S, Lebanony D, Yerushalmi N, Benjamin H, Kushnir M, Cholakh H, Melamed N, Bentwich Z, Hod M, Goren $Y$, Chajut A: Serum microRNAs are promising novel biomarkers. PLOS ONE 2008, 3:e3148.

29. Mitchell PS, Parkin RK, Kroh EM, Frits BR, Wyman SK, PogosovaAgadjanyan EL, Peterson A, Noteboom J, O'Briant KCO, Allen A, Lin DW, Urban N, Drescher CW, Knudsen BS, Stirewalt DL, Gentleman R, Vessella RL, Nelson PS, Martin DB, Tewari M: Circulating microRNAs as stable bloodbased markers for cancer detection. Proc Natl Acad Sci USA 2008, 105:10513-10518. 
30. Heneghan HM, Miller N, Lowery AJ, Sweeney KJ, Newell J, Kerin MJ: Circulating microRNAs as novel minimally invasive biomarkers for breast cancer. Ann Surg 2010, 251:499-505.

31. Van der Auwera I, Elst HJ, Van Laere SJ, Maes H, Huget P, van Dam P, Van Marck EA, Vermeulen PB, Dirix LY: The presence of circulating total DNA and methylated genes is associated with circulating tumour cells in blood from breast cancer patients. Br J Cancer 2009, 100:1277-1286.

32. Van der Auwera I, Peeters D, Benoy $H$, Elst HJ, Van Laere SJ, Prové A, Maes $H$, Huget $P$, van Dam $P$, Vermeulen PB, Dirix LY: Circulating tumour cell detection: a direct comparison between the CellSearch System, the AdnaTest and CK-19/mammaglobin RT-PCR in patients with metastatic breast cancer. Br J Cancer 2010, 102:276-284.

33. Therasse P, Arbuck SG, Eisenhauer EA, Wanders J, Kaplan RS, Rubinstein L, Verweij J, Van Glabbeke M, van Oosterom AT, Christian MC, Gwyther SG: New guidelines to evaluate the response to treatment in solid tumors: European Organization for Research and Treatment of Cancer, National Cancer Institute of the United States, National Cancer Institute of Canada. J Natl Cancer Inst 2000, 92:205-216.

34. Sieuwerts AM, Mostert B, Bolt-de Vries J, Peeters D, de Jongh FE, Stouthard JM, Dirix LY, van Dam PA, Van Galen A, de Weerd V, Kraan J, van der Spoel P, Ramírez-Moreno R, van Deurzen CH, Smid M, Yu JX, Jiang J, Wang Y, Gratama JW, Sleijfer S, Foekens JA, Martens JW: mRNA and microRNA expression profiles in circulating tumor cells and primary tumors of metastatic breast cancer patients. Clin Cancer Res 2011, 17:3600-3618.

35. Mestdagh $P$, Van Vlierberghe $P$, De Weer A, Muth D, Westermann F, Speleman F, Vandesompele J: A novel and universal method for microRNA RT-qPCR data normalization. Genome Biol 2009, 10:R64.

36. Livak KJ, Schmittgen TD: Analysis of relative gene expression data using real-time quantitative PCR and the 2(-Delta Delta C(T)) Method. Methods 2001, 25:402-408.

37. Parker JS, Mullins M, Cheang MC, Leung S, Voduc D, Vickery T, Davies S, Fauron C, He X, Hu Z, Quackenbush JF, Stijleman IJ, Palazzo J, Marron JS, Nobel AB, Mardis E, Nielsen TO, Ellis MJ, Perou CM, Bernard PS: Supervised risk predictor of breast cancer based on intrinsic subtypes. J Clin Oncol 2009, 27:1160-1167.

38. Van Laere S, Van der Auwera I, Van den Eynden G, Van Hummelen P, van Dam P, Van Marck E, Vermeulen PB, Dirix L: Distinct molecular phenotype of inflammatory breast cancer compared to non-inflammatory breast cancer using Affymetrix-based genome-wide gene-expression analysis. Br J Cancer 2007, 97:1165-1174.

39. Van der Auwera I, Yu W, Suo L, Van Neste L, van Dam P, Van Marck EA, Pauwels P, Vermeulen PB, Dirix LY, Van Laere SJ: Array-based DNA methylation profiling for breast cancer subtype discrimination. PLOS ONE 2010, 5:e12616.

40. Van der Auwera I, Limame R, van Dam P, Vermeulen PB, Dirix LY, Van Laere SJ: Integrated miRNA and mRNA expression profiling of the inflammatory breast cancer subtype. Br J Cancer 2010, 103:532-541.

41. Cheng C, Fu X, Alves P, Gerstein M: mRNA expression profiles show differential regulatory effects of microRNAs between estrogen receptorpositive and estrogen receptor-negative breast cancer. Genome Biol 2009, 10:R90.

42. Dedes KJ, Natrajan R, Lambros MB, Geyer FC, Lopez-Garcia MA, Savage K, Jones RL, Reis-Filho JS: Down-regulation of the miRNA master regulators Drosha and Dicer is associated with specific subgroups of breast cancer. Eur J Cancer 2011, 47:138-150.

43. Janssen EAM, Slewa A, Gudlaugsson E, Jonsdottir K, Skaland I, Søiland H, Baak JP: Biologic profiling of lymph node negative breast cancers by means of microRNA expression. Mod Pathol 2010, 23:1567-1576.

44. Bockmeyer CL, Christgen M, Müller M, Fischer S, Ahrens P, Länger F, Kreipe $H$, Lehmann $U$ : MicroRNA profiles of healthy basal and luminal mammary epithelial cells are distinct and reflected in different breast cancer subtypes. Breast Cancer Res Treat 2011.

45. Lowery AJ, Miller N, Devaney A, McNeill RE, Davoren PA, Lemetre C, Benes V, Schmidt S, Blake J, Ball G, Kerin MJ: MicroRNA signatures predict oestrogen receptor, progesterone receptor and HER2/neu receptor status in breast cancer. Breast Cancer Res 2009, 11:R27.

46. Castellano L, Giamas G, Jacob J, Coombes RC, Lucchesi W, Thiruchelvam P, Barton G, Jiao LR, Wait R, Waxman J, Hannon GJ, Stebbing J: The estrogen receptor-alpha-induced microRNA signature regulates itself and its transcriptional response. Proc Natl Acad Sci USA 2009, 106:15732-15737.
47. Liu S, Goldstein RH, Scepansky EM, Rosenblatt M: Inhibition of rhoassociated kinase signaling prevents breast cancer metastasis to human bone. Cancer Res 2009, 69:8742-8751.

48. Li H, Bian C, Liao L, Li J, Zhao RC: miR-17-5p promotes human breast cancer cell migration and invasion through suppression of HBP1. Breast Cancer Res Treat 2011, 126:565-575.

49. Ma X, Becker Buscaglia LE, Barker JR, Li Y: MicroRNAs in NF-kappaB signaling. J Mol Cell Biol 2011, 3:159-166.

50. Herschkowitz JI, Zhao W, Zhang M, Usary J, Murrow G, Edwards D, Knezevic J, Greene SB, Darr D, Troester MA, Hilsenbeck SG, Medina D, Perou CM, Rosen JM: Breast Cancer Special Feature: Comparative oncogenomics identifies breast tumors enriched in functional tumorinitiating cells. Proc Natl Acad Sci USA 2011.

51. Gregory PA, Bracken CP, Smith E, Bert AG, Wright JA, Roslan S, Morris M, Wyatt L, Farshid G, Lim YY, Lindeman GJ, Shannon MF, Drew PA, KhewGoodall Y, Goodall GJ: An autocrine TGF-beta/ZEB/miR-200 signaling network regulates establishment and maintenance of epithelialmesenchymal transition. Mol Biol Cell 2011, 22:1686-1698.

52. Gregory PA, Bert AG, Paterson EL, Barry SC, Tsykin A, Farshid G, Vadas MA, Khew-Goodall Y, Goodall GJ: The miR-200 family and miR-205 regulate epithelial to mesenchymal transition by targeting ZEB1 and SIP1. Nature 2008, 10:593-601.

53. Yu F, Yao H, Zhu P, Zhang X, Pan Q, Gong C, Huang Y, Hu X, Su F, Lieberman J, Song E: let-7 regulates self renewal and tumorigenicity of breast cancer cells. Cell 2007, 131:1109-1123.

54. Song B, Wang Y, Titmus MA, Botchkina G, Formentini A, Kornmann M, Ju J: Molecular mechanism of chemoresistance by miR-215 in osteosarcoma and colon cancer cells. Mol Cancer 2010, 9:96

55. Duan Z, Person RE, Lee H-H, Huang S, Donadieu J, Badolato R, Grimes HL, Papayannopoulou T, Horwitz MS: Epigenetic regulation of protein-coding and microRNA genes by the Gfi1-interacting tumor suppressor PRDM5. Mol Cell Biol 2007, 27:6889-6902.

56. Fang X, Yoon J-G, Li L, Yu W, Shao J, Hua D, Zheng S, Hood L, Goodlett DR, Foltz G, Lin B: The SOX2 response program in glioblastoma multiforme: an integrated ChIP-seq, expression microarray, and microRNA analysis. BMC Genomics 2011, 12:11.

57. Lavon I, Zrihan D, Granit A, Einstein O, Fainstein N, Cohen MA, Cohen MA, Zelikovitch B, Shoshan Y, Spektor S, Reubinoff BE, Felig Y, Gerlitz O, BenHur T, Smith Y, Siegal T: Gliomas display a microRNA expression profile reminiscent of neural precursor cells. Neuro Oncol 2010, 12:422-433.

58. Hunter MP, Ismail N, Zhang X, Aguda BD, Lee EJ, Yu L, Xiao T, Schafer J, Lee ML, Schmittgen TD, Nana-Sinkam SP, Jarjoura D, Marsh CB: Detection of microRNA expression in human peripheral blood microvesicles. PLOS ONE 2008, 3:e3694.

59. Arroyo JD, Chevillet JR, Kroh EM, Ruf IK, Pritchard CC, Gibson DF, Mitchell PS, Bennett CF, Pogosova-Agadjanyan EL, Stirewalt DL, Tait JF, Tewari M: Argonaute2 complexes carry a population of circulating microRNAs independent of vesicles in human plasma. Proc Natl Acad Sci USA 2011, 108:5003-5008.

60. Vickers KC, Palmisano BT, Shoucri BM, Shamburek RD, Remaley AT: MicroRNAs are transported in plasma and delivered to recipient cells by high-density lipoproteins. Nat Cell Biol 2011, 13:423-433.

61. Valadi H, Ekström K, Bossios A, Sjöstrand M, Lee JJ, Lötvall JO: Exosomemediated transfer of mRNAs and microRNAs is a novel mechanism of genetic exchange between cells. Nat Cell Biol 2007, 9:654-659.

62. Muralidharan-Chari V, Clancy JW, Sedgwick A, D'Souza-Schorey C: Microvesicles: mediators of extracellular communication during cancer progression. J Cell Sci 2010, 123:1603-1611.

63. Pigati L, Yaddanapudi SC, lyengar R, Kim DJ, Hearn SA, Danforth D, Hastings ML, Duelli DM: Selective release of microRNA species from normal and malignant mammary epithelial cells. PLOS ONE 2010, 5: e13515.

\section{doi:10.1186/bcr3127}

Cite this article as: van Schooneveld et al:: Expression profiling of cancerous and normal breast tissues identifies microRNAs that are differentially expressed in serum from patients with (metastatic) breast cancer and healthy volunteers. Breast Cancer Research 2012 14:R34. 